\title{
Beschouwingen over de Fauna van Nederland
}

\author{
DOOR
}

MAX WEBER.

Een aantal maanden geleden vergastte Dr. C. Kenbert de lezers der "Levende Natuur" op "Faunistische Aanteekeningen", die in boeienden vorm van zoologische vondsten uit de omstreken van Amsterdam vertelden, zooals vervlogen dagen ze opleverden.

Die "faunistische aanteekeningen" waren slechts enkele schakels uit een langen keten van faunistisch werk, dat gedurende een lange reeks van jaren Dr. Kerbert bezig hield.

Schier alle groepen van het dierenrijk hebben daarbij in meerdere of mindere mate zijn aandacht getrokken en onitrent velen mocht het dankbare publiek wetenswaardigs vernemen.

Deze regels willen uiting geven aan de gevoelens van een veertigjarige vriendschap met den man wiens zeventigsten geboortedag velen in den lande met ingenomenheid herdenken, zij willen tevens een. bewijs geven van hoogachting voor het levenswerk van den jubilaris.

Ik meen dit niet beter te kunnen doen, dan door een bijdrage voor dezen feestbundel te leveren, die enkele vraagpunten der nederlandsche fauna behandelt.

Allen zijn. het er over eens, dat het karakter der dierenwereld van een bepaald gebied in de eerste plaats afhankelijk is van de geographische ligging van dat gebied, maar daar: naast in nauwelijks mindere mate van zijn wordingsgesehiedenis en van de wordingsgeschiedenis der fauna zelve.

Weliswaar bepaalt de geographische ligging de levensvoorwaarden der dieren en van dat gezichtspunt uit zijn zij producten van hun omgeving; maar dit is niet het eenige moment. De dierenwereld van een gebied, zijn fauna, is in meerdere of mindere mate een mengsel, dat zich slechts uit het verleden laat verklaren.

Met „wordingsgeschiedenis van een gebied" bedoelen wij de veranderingen in de verdeeling van land en water, die bovenal sedert het tertiaire tijdperk van ingrijpenden invloed waren op de versprijding der dieren. Verhuizing naar en uit een landstreek en daarmede de mogelijkheid tot vermenging van oorspronkelijk gescheiden faunagebieden, vordert landverbindingen, wier ontstaan of opheffing geologische gebeurtenissen zijn, die buiten onze beschouwing vallen.

Hand in hand daarmede of onafhankelijk daarvan konden evenwel klimatische veranderingen plaats hebben. En dat „klimaat" de belangrijkste levensvoorwaarden voor de dieren omvat, is duidelijk genoeg wanneer wij in het oog houden, dat klimaat een meteorologisch begrip is van zeer ruimen omvang. Het is toch het geheel van meteorologische verschijnselen, die de temperatuur, de vochtigheid, de mate van verlichting, de geaardheid van den bodem en het plantenkleed beheerschen. En nademaal de dieren direct afhankelijk zijn van het 
plantenkleed als voedselbron, van de geaardheid van den bodem, van de vochtigheid van bodem en lucht, van den graad van insolatie, en van de temperatuur, zal elke verandering hierin van invloed zijn op de verspreiding der dieren en daardoor op het karakter der fauna. Verandering toch der levensvoorwaarden moet verhuizing of uitsterven van degenen, die zich niet kunnen aanpassen aan de veranderde toestanden, ten gevolge hebben; zij kan voor anderen aanleiding tot immigratie zijn en weer anderen wellicht tot omvorming leiden.

De tegenwoordige verspreiding der dieren is derhalve in de eerste plaats het resultaat van de wordingsgeschiedenis der landen en van hun dierenwereld; zij vloeit dus voort uit het verleden en is slechts door de kennis van het verleden begrijpelijk.

De zooeven aangeduide verhuizingen, voortvloeiende uit klimatische veranderingen in de ruimste beteekenis, zijn niet de eenige. Migratie heeft ook plaats tengevolge van de vrij algemeene tendentie der dieren zich te vermenigvuldigen boven de mogelijkheid van instandhouding in een gegeven gebied. Onder gewone omstandigheden zal evenwel de vernietiging door natuurlijke vijanden of door kosmische invloeden bet aantal nakomelingen op zoodanig peil houden, dat de instandhouding der soort verzekerd is zonder overvloedige toename.

Die evenwichtstoestand kan verbroken worden, zonder dat de oorzaken daarvoor steeds duidelijk zijn.

Bovenmatig talrijk optreden eener diersoort kan immers van zeer versehillenden aard zijn. Bịj uitzondering zijn er gevallen met een bepaalde periodiciteit. De ontwikkeling van den meikever strekt zich uit over 3-4 jaren ${ }^{1}$ ). Er zijn derhalve in een gegeven streek gelijktijdig 3-4 gescheiden volken in ontwikkeling, waarvan een het rijkst aan individuën is en aanleiding geeft tot een meikeverjaar. Deze treden dus in streken waar de meikever over het algemeen talrijker is, om de 3 of 4 jaren op. Daar zij vrijwel onafhankelijk blijken te zijn van uitwendige invloeden, veronderstelt men, dat de grootste meikeverlarven de kleineren van de volgende generaties opvreten. Wanneer dit gebeurt door een volk met talrijke individuën, zal het de volgende generaties belangrijk decimeeren, terwijl zijn directe nakomelingen over 3 of 4 jaren weer de talrijkste zullen zijn.

In de meeste gevallen zullen het echter uitwendige oorzaken zijn, die een buitengewone vermenigvuldiging eener soort in de hand werken.

Zoo hebben uitgebreide studiën vooral van Hofrman, Hozk en RedeKE; die evenwel nog dienen voortgezet te worden, het niet onwaarschijnlijk gemaakt, dat de groote jaarlijksche schommelingen in de ansjovis-vangst in de Zuiderzee afhankelijk zijn van de temperatuur vooral van Juni en gedeeltelijk van Juli van het voorafgaande jaar. Dit zijn immers de maanden waarin voornamelijk de ontwikkeling der ansjovis-larven in de Zuiderzee plaats heeft. Zijn in die maanden de omstandigheden, en wel in de eerste plaats de temperatuur, gunstig voor de voeding en ontwikkeling van het gevoelige ansjovisbroed, zoodat zich een groot aantal larven tot vischjes ontwikkelt, die in het najaar als onrijpe ansjovis de Zuiderzee verlaten, dan zal allicht de geslachtsrijpe ansjovis, die in Mei van het volgende jaar de Zuiderzee weer binnentrekt, grooter in aantal zijn en een goed ansjovisjaar leveren.

Overproduktie die van haar. kant aanleiding tot migratie kan geven, is uit den aard der zaak het eerst te verwachten bij soorten, die op zich zelve uiterst vruchtbaar zijn en waar tevens reeds na kortstondige ontwikkeling voortplanting mogelijk is.

Beroemd voor zijn neiging tot overproductie is de Lemming (Lemmus lemmus L.). Een ongewoon groot aantal jongen zal geboren worden en tot voortplanting komen, - waarvoor zij slechts 8-10 weken oud behoeven te zijn, - als in hun woongebied in het hooge Noorden of in het hooggebergte van Skandinavië het voorjaar vroeg, de zomer drooger en warmer dan anders is. Spoedig is hun omgeving kaalgevreten. De naar nillioenen tellende dieren, door honger en door een suggestieven drang tot trekken voortgedreven, overstroomen in groote scharen de lage landen. Hier gaan zij een wissen dood te gemoet: deels door talrijke vijanden, 
meer, nog, tengevolge van septicaemie veroorzaakt door de ook voor andere knaagdieren uiterst besmettelijke "Lemming-Bacterie":

Soortgelijk phenomeen ontmoeten wij bij onze "muizen-jaren”. Ook hier moet de groote productiviteit, die aan de veldmuis eigen is, ondersteund. worden door voor de ontwikkeling gunstige voorwaarden, waarbij de weersgesteldheid wel de voornaamste rol zal spelen. Ook hier zal voedselgebrek tot migratie aanleiding. geven, al is het ook op veel bescheidener schaal dan bij de lemming. Beiden kunnen op die wijze in het verleden actief allengs. het groote gebied veroverd hebben, dat zij thans bewonen.

Er wordt beweerd, dat in recenten tijd zulks zou plaats gehad hebben met de bruine rat (Mus norvegicus), die daarom bij de Duitschers "Wanderratte" genoemd wordt. Pallas beeft zelfs het jaar $172 \%$ als tijdstip genoemd, waarop zij, uit haar woonplaats in het Kaspische gebied komende het eerst de Wolga overtrok om zich steeds westwaarts uitbreidende tenslotte de heele wereld te veroveren, gebruik makende van de steeds meer zich ontwikkelende transportmiddelen van den mensch. Maar bovengenoemde datum van invasie kan voor de kritiek geen stand houden, wat echter niet zeggen wil, dat de bruine rat niet in den loop der tijden door verhuizing naar het westen tot ons zou gekomen zijn..

Ook in andere groepen kan massaal optreden tot trekken en- daarmede tot verspreiding aanleiding geven. Zoo is b.v. bekend, dat de vlinder Pyrameis cardui L., de zoog. "distelvink" in sommige streken van oostelijk Europa om de 6 tot 8 jaar in verbazend groot aantal ver-: schijnt. In 1903 werden op vele plaatsen in Europa groote trekkende zwermen waargenomen, zoo ook in ons land, waar de vlinder anders niet gewoon is. Anderen trokken zelfs bij nacht het Kanaal over naar Engeland. Er is trouwens gebleken, dat meer insekten uit verschillende orden bij gunstigen wind van het vasteland naar de Britsche kusten oversteken.

In de literatuur vindt men veelvuldig opgaven van groote insektenzwermen. Dat tal van gunstige uitwendige omstandigheden moeten samenwerken om tot zoodanige overproductie te leiden, is duidelijk, en dat zij tot uitbreiding der soort kan leiden, is al evenmin een voorbarig besluit. Maar daarbij mag niet vergeten worden, dat zulke invasies zonder resultaat zullen blijven, als de levensvoorwaarden in het nieuwe gebied niet geheel beantwoorden aan de eischen eener soort, en die zijn ons niet altijd even duidelijk. Dat leert b.v. het steppenhoen Syrrhaptes paradoxus Pall. uit de centraal aziatische steppen, dat in 1859 voor het eerst in enkele exemplaren in onze duinen werd aangetroffen. In 1863 en 1864 bezochten groote vluchten ons land, in 1888 in die mate, dat van April tot December in alle provincies exemplaren vertoefden, enkele koppels in Noord- en Zuid-Holland en Gelderland tot September 1889. Het kwam zelfs tot broeden, maar overigens bleven de invasies, die op kleinere schaal in 1906 en 1908 herhaald werden, zonder resultaat. Anders in Zuid-oost Europa, waar het steppenhoen sedert de invasie van 1863 werkelijk voet gevat heeft.

Verhuizing eener soort in het groot, waarvoor wij boven voorbeelden aanhaalden, kan aanleiding geven tot verovering van een nieuw woongebied. Nader toezien leert evenwel, en latere voorbeelden zullen het bevestigen, dat het hierbij meestal om eene verovering van slechts: zeer korten duur gaat. Gemeenlijk blijven enkele individuën in de nieuwe woonplaats over, die op den duur ook geen stand houden.

Van meer beteekenis dan een massale immigratie kan het verhuizen van enkelingen zijn, dat bij herhaling gebeurt. Van enkele vlindersoorten zooals de „Oleander-Pijlstaart". Deilephila nerii L. en D. celerio L. - en J. Tн. Oudemans heeft het overtuigend ook roor den "Doodshoofdvlinder" (Acherontia atropos L.) vastgesteld ") - is bekend, dat zij bij ons geen stamsoorten zijn, maar dat zij telkens in den voorzomer in kleiner of grooter getal uit naburige landen ons land bezoeken en hier eieren leggen, welke nog voor den winter imagines leveren. Maar aan een nieuwe generatie kunnen zij in ons klimaat geen aanzijn schenken.

Dit zijn actieve verhuizingen, die weliswaar zonder resultaat blijven, maar zij geven een beeld hoe door zulke geleidelijke verhuizing menige soort stap voor stap terrein gewonnen 
en haar woongebied uitgebreid heeft. Dat zien wij onder onze oogen gebeuren bij het korhoen (Lyrurus tetrix (L.)). Uit het onderzoek van L. F. DE BEadeonT ${ }^{1}$ ) blijkt, dat het, vroeger beperkt tot de oostelijke provincies van ons land, gedurende de laatste 20 jaren zich over het geheele diluviale gebied heeft verspreid en slechts in Zuid-Holland en Zeeland nog ontbreekt. Ook de zwarte roodstaart. (Phoenicurus titys L.) heeft zich gaandeweg over het geheele land verbreid ${ }^{2}$ ), en van de zanglijster (Turdus musicus L.) en enkele andere vogels is eveneens uitbreiding van het woongebied waargenomen, In den allerlaatsten tijd ook bij den zwarten specht (Dryocopus martius L.). In 1858 werd hij het eerst voor Nederland opgegeven en wel van Twello, in 1884 van Menaldumadeel. Later werd hij van Zuidlaren en Zwolle vermeld en allengs van steeds talrijkere en meer westelijk gelegen plaatsen zooals Eerbeek, Laag-Soeren, Amersfoort en zelfs een paartje uit de Scheveningsche boschjes. Het geldt hier niet "gasten", zooals, zij onder vogels zoo talrijk zijn, maar broedvogels ${ }^{3}$ ). Wellicht bestaat er kans dat ook de eidergans (Somateria mollissima L.) een broedvogel bij ons wordt ${ }^{4}$ ). Een jaarlijksch bezoeker onzer kusten is zij in toenemende mate ook broedend aangetroffen. Dat zou dan een immigrant uit meer verwijderde gewesten zijn.

Maar er zijn meer voorbeelden voor langzame uitbreiding, ook uit groepen, aan wie men op het eerste gezicht nauwelijks het vermogen van actieve verspreiding zou willen toekennen.

Zoo vertelt KobeLi ${ }^{5}$ ) van het overbrengen van de europeesche slakken Helix hortensis en nemoralis door amerikaansche conchyologen naar Noord-Amerika. Beide soorten hebben zich snel verspreid van het punt waar zij uitgezet werden. En reeds 1890 gaf Musson ${ }^{6}$ ) 20 in Australië, Tasmanië en Nieuw-Zeeland geacclimatiseerde Land- en Zoetwater-Mollusken op, waarvan er 19 uit Europa waren ingevoerd. Twee er van: onze gewone Limax agrestis L. en Limax variegatus Drap. zijn thans in Nieuw-Zeeland algemeen verspreid, trouwens ook in andere cultuurlanden, waar zij b.v. met planten werden ingevoerd.

Dit zijn opmerkelijke feiten, vooral bij dieren zooals slakken, met een gering verplaatsingsvermogen en groote gevoeligheid voor geaardheid van bodem en lucht. Vele anderen missen dan ook zulk aanpassingsvermogen. Zoo bleef Planorbis dilatatus Gould, die vóór 1869 met vochtige katoenbalen uit Amerika in Manchester werd ingevoerd, sedert dien beperkt tot de omgeving der fabrieken. Een treffender voorbeeld voor het schijnbaar wispelturige in deze materie levert Cyclostoma elegans. Deze huisjesslak leeft in het westelijk continentale Europa en in Engeland. Zij wordt telkens aan de kusten van Jerland aangespoeld aangetroffen. Darwin heeft experimenteel aangetoond, dat zij, dank zij haar deksel, een 14 dagen lange onderdompeling in zeewater kan verduren. Terecht wijst ScharfF ${ }^{7}$ ) op het raadselachtige, dat zij desniettemin, niettegenstaande zeestroomingen haar gedurende ontelbare jaarhonderden naar de kusten van Ierland transporteerden, daar nimmer voet kon vatten en dus op dat eiland ontbreekt.

Soortgelijke raadselachtige verscheidenheid ontmoet men ook bij andere diergroepen. Men kent b.v. van kevers talrijke soorten, die met zaden, hout, vruchten en andere handelswaren van elders ook naar onze gewesten of omgekeerd vervoerd werden. Vele zullen in de nienwe omgeving na korteren of langeren duur te gronde gaan. Maar Everts ${ }^{8}$ ) b.v. kon een lange lijst van zulke wereldburgers opmaken, die in allerlei waren in schepen, pakhuizen, kelders ingevoerd, zich ook bij ons in die waren vermenigvuldigden. Er zijn er onder b.v. Corynetes coeruleus, Dermestes-soorten e.a., die vrijlevend zich allengs over een groot deel der aarde verspreid hebben.

1) L. F. DE BEAUFORT, Ardea 1912, p. 50 .

2) Snouckaert van Schauburg, Falco 1907 , p. 69, en Avifauna neerlandica 1908, p. 48

3) In het Jaarbericht 7, 1917, van den club van Nederl. Vogelkundigen, p. 13 en p. 99 worden twee gevallen van het broeden van den Zwartspecht bij Ommen en te Raalte (O.) medegedeeld.

4) E. D. VAN OoRT, Notes Leyden Museum XXX. 1901. p. 153.

5) W. Konelt, Studien zur Zoogeographie. Die Mollusken d. palaearkt. Region. 1897, p. 29

6) Musson, Proc. Linn. Soc. New South Wales. 1890.

7) ScharfF, History of European Fauna. 1899. p. 16.

8) E. EverTs, Verslag Ned. Entom. Vereen. 68. Vergad. 1913. 
Men heeft dergelijke soorten cenokosmisch genoemd in tegenstelling met palinkosmische, die reeds in vroegere perioden der aardgeschiedenis eene wijde versprijding hadden. De onderscheiding zal moeilijk zijn, maar de gedachte is zeker juist, dat er factoren zijn, die evengoed als thans zoo ook in een ver verleden verspreiding der soorten mogelijk maakten en daarmede van invloed waren op de samenstelling der fauna. Want evengoed als thans werd ook vroeger verspreiding naar een nieuw gebied mogelijk gemaakt door transport. Dat kon en kan nog geschieden door drijfhout of andere drijvende voorwerpen, die over zee komende aan de kusten geworpen worden. Daaraan danken wij vermoedelijk de boorschelp Petricola pholadiformis, die oorspronkelijk aan de Oostkust van Noord-Amerika thuis behoort. Het eerst werd zij in 1908 door Juffrouw H. ICKe ${ }^{1}$ ) bij Noordwijk aangetroffen; later vond men exemplaren, in veenbanken ingeboord, bij den Helder en verder langs onze kust. Zij heeft vermoedelijk haar weg over Engeland genomen, van waar zij sedert 1896 van Essex en Kent bekend is, sedert 1903 ook van Ostende.

Van soortgelijke transportmiddelen kan ook op rivieren gebruik gemaakt worden. Hoog water op de bovenrivier geeft aanleiding, dat "aanspoelsel" naar beneden vervoerd wordt. Entomologen en conchyologen weten maar al te goed hoeveel dieren in zulk "aanspoelsel" van hout, riet enz. meegevoerd worden. In den loop der tijden zal menige oorspronkelijke vreemdeling door deze reisgelegenheid zijn woongebied uitgebreid hebben.

Belangrijker transportmiddel, althans voor kleine organismen, is de wind, die zeker de grootste rol gespeeld heeft om de zoete wateren naast locale vormen met talrijke universele te bevolken. De kiemen van Zoetwater-Bryozoën en van een aantal Zoetwatersponzen zijn op windtransport ingericht, terwijl door krachtigen wind meegevoerde bladeren een transportmiddel leveren voor kleine Mollusken, Insecten en voor kiemen van andere dieren.

Onder de natuurlijke transportmiddelen tellen ook trekkende dieren op wier haren of veeren andere dieren of hun eieren zich hechten. Mollusken, hun eieren, Insecten, Crustaceen, Wormen kunnen op die wijze soms over groote afstanden vervoerd worden.

Het bovenstaande leert, dat wij een actieve en passieve verspreiding onderscheiden kunnen. Om met Forki ${ }^{2}$ ) te spreken zal de actieve in den regel een normale migratie zijn, aangezien zij langs, voor het organisme natuurlijke verkeerswegen plaats heeft, zonder dat het organisme genoodzaakt is daarbij van een hem vreemd milieu gebruik te maken of van eene hem vreemde wijze van verplaatsing. Omgekeerd zal in den regel de passieve migratie eene abnormale zijn, omdat zij plaats heeft langs een milieu, dat aan het organisme vreemd is of op eene wijze, die verschilt van zijn eigen locomotie en bovendien meestal zuiver toevallig is. Dat is het geval bij organismen of hun kiemen, die door stroomend water, door wind, in de veeren, aan de pooten of in den darminhoud van vogels, aan de haren van zoogdieren of door andere transportmiddelen vervoerd worden.

Maar er is ten aanzien der passieve verspreiding meer in acht te nemen. Naast de genoemde transportmiddelen, die ik natuurlijke zou willen noemen, daar zij van oudsher werkzaam waren en evengoed als thans ook in het verleden en bij het scheppen der palinkosmische fauna-elementen een rol speelden, is met het verschijnen van den mensch allengs een nieuwe factor ontstaan.

Hij schiep transportmiddelen, die steeds talrijker en veelzijdiger worden en in steeds toenemende mate verwijderde landstreken in verbinding brengen.

Wij willen door enkele voorbeelden, die aan onze fauna ontleend zijn, op de beteekenis van dit ingrïpen van den mensch wïzen.

Terecht berucht is de paalworm (Teredo navalis L.) door zijn boorschade aan schepen en havenwerken; minder bekend is de schade veroorzaakt door den "scheepsworm" (T'eredo megotara Hanl.), die volgens $R_{\text {EDEKE }}{ }^{3}$ ) onze in de noordelijke Noordzee visschende houten vaartuigen aantast en aldus bij ons geimporteerd is. Onder, bizondere, voor het dier gunstige

1) H. IckE, Tijdschr. Ned. Dierk. Vereen. (2) X. 1908, p. 226.

2) F. A. ForEl, Le Léman. T. III, 1904

3) H. C. REvekE, Rapport over onderzoekingen betreff, h. voorkomen v. d. scheepsworm (Teredo megotara Hanl.). 1912. 
omstandigheden blijft hij hier in het leven en vermenigvuldigt zich zooals in de Visschershaven van Scheveningen.

Interessanter is de levensgeschiedenis van een ander Mollusk: de naaktslak Corambe batava, door Kerber' ${ }^{1}$ ) in 1881 in de Zuiderzee bij Durgerdam ontdekt. Het geslacht Corambe was toen alleen uit de Sargasso-zee-bekend. De hypothese was dus niet te gewaagd, dat tusschen wieren aan de huid van schepen, die op weg naar Amsterdam, de Sargasso-zee passeerden, levende exemplaren van Corambe in de Zuiderzee geimporteerd werden. Dit was immers in vervlogen dagen de weg tot Amsterdam, meestal met een oponthoud bij het Pampus (bij Durgerdam!). Later werd dan ook Corambe bij Wieringen ${ }^{2}$ ) en bij den Helder ${ }^{3}$ ) aangetroffen en buitendien alleen nog maar in de haven van Arcachon.

Verkeerdelijk is vaak de meening verspreid, dat de zonderlinge mossel Dreissena polymorpha in de vorige eeuw aan de huid van schepen uit de Kaspische Zee in de zoete en brakke wateren van West-Europa en dus ook bij ons was ingevoerd. Dit is in dien vorm onjuist. Dreissena polymorpha kan niet in zeewater leven, kan dus geen lange zeereis doorstaan. Als zij dus uit het pontische gebied, b.v. uit Zuid-russische rivieren tot ons gekomen is, kan dit alleen geschied zijn door vochtig timmerhout, in schepen aangevoerd; hare levenstaaibeid kan daarbij meêwerken. Maar de zaak wordt ingewikkelder, omdat men haar bovendien fossiel uit de keileem van Pruissen, en uit lagen 15 voet diep onder het tegenwoordige Londen kent, uit een tijd dus, waarin vervoer, als boven aangeduid; uitgesloten was. $\mathrm{Zij}$ is dus eerder als een relict te beschouwen, dat zich in enkele noord-europeesche wateren staande hield en van daar weer verder verspreidde.

Ook van de binnenruimte van șchepen kunnen dieren een tijdelijke woonplaats maken en aldus van verweg vervoerd worden. Insecten, spinnen, duizendpooten, slangen, de Gecko (Gecko verticillatus Laur.), de Tjitjak (Hemidactylus frenatus Dum. \& Bibr.), ratten, muiźen e.a. worden op die wijze in onze havenplaatsen gebracht. Onze fauna wordt er niet door verrijkt, want behalve ratten en muizen, kunnen deze meestal tropische vreemdelingen bij ons niet aarden.

Belangrijker is de invoer van vreemde dieren in handelswaren, vooral in granen, zaden, Arachiden-nooten, vruchten, vezelstoffen, in hout, op levende planten, in de aardkluiten om haar wortels e.d.m. Ook hier is den meesten in ons klimaat slechts een kortstondig bestaan beschoren. Anderen, vooral met een verborgen levenswijze, houden zich staande.

Boven werd reeds aangeduid, dat heel wat uitheemsche-torren onze graan- en rijstpakhuizen bewonen. Ik noem slechts Laemophloeus ferrugineus Steph., Silvanus surinamensis L., 'Trogosita mauritanica L., Rhizopertha dominica F., Calandra-soorten. Weer anderen: Tribolium ferrugineum F., Bruchus chinensis L. en Br. mimosae F. houden zich op in magazijnen met aardnooten, peulvruchten, sesamzaden e.d.m.

Dan zijn er immigranten uit warme luchtstreken, die zich bij ons ingeburgerd hebben in verwarmde lokalen. Zoo de beruchte Pharaomier (Monomorium pharaonis L.), die vooral in bakkerijen aangetroffen wordt, maar ook menig ander gebouw zooals het postkantoor te Alkmaar, onbewoonbaar gemaakt heeft. Meer bekend zijn de door het handelsverkeer uit Amerika en Azië ingevoerde kakkerlakken (Periplaneta) en de uit oostelijk Europa over de geheele aarde verspreide Phyllodromia germanica L.

Heel wat organismen worden telkens ingevoerd met levende planten. Zijn het tropenbewoners, dan zijn verwarmde kassen de eenige plaats waar hun voortbestaan verzekerd is. Uit onze naaste omgeving wil ik slechts noemen den platworm Bipalium kewense, die b.v. sedert jaren het Reptiliënhuis van "Artis" bewoont. Hij is trouwens ook overigens uitsluitend in verwarmde plantenkassen en dergelijke plaatsen aangetroffen, terwijl men zijn tropisch of subtropisch vaderland niet kent. Dat is ook het geval met de spin Theridium tepidariorum C. L. Koch, die ook bij ons in zulke verwarmde localiteiten gevonden is. Hetzelfde is het

1) C. Kerbert, Tijdschr. Ned. Dierk. Ver. (2) I. 1886, Versi. p. 5.

2) M. WebEr. Tijdschr. Ned. Dierk. Ver. (2) I. Versl. Verg. 1886, p. CLXX en ibid. (2) II. Versl. Verg. 1887, p. XVII

3) J. J. Tesch, Tijdschr. Ned. Dierk. Ver. (2) XII. Versl: Verg. 1912, p. LXXXIX. 
geval met het Mollusk Opeas goodalli Mill, dat volgens Juffrouw J. SchoLten in 1912 en 1913 herhaaldelijk in de warme kas van den Hortus botanicus te Amsterdam werd aangetroffen. Een plaag in vele van onze kassen is voorts de ingevoerde duizendpoot Paradesmus gracilis Koch, opmerkelijk door zijn vermogen om door huidklieren vrij blauwzuur af te scheiden.

Men zal de genoemde dieren niet bij. onze fauna mogen rekenen; maar anderen zijn er, die allengs daarop aanspraak mogen maken. De zuideuropeesche slak Physa acuta Drap. werd ongeveer in 1909 in ons land het eerst door Jhr. W. C. van Heurn in de Victoria regiakas te Leiden gevonden, in 1912 door Juffrouw J. Scholten in soortgelijk bassin in den Hortus te Amsterdam. In December 1915 vond C. Druyvestein 2 exemplaren vrijlevend in het Noorderspaarne bij Schoten en op 31 Juli 1916 de Heer Thiellier exemplaren te Teteringen bij Breda. Dit is allengs algemeen bekend geworden; daarbij heeft men, zooals mij onlangs bleek, vergeten, dat de soort reeds in 1870 door E. v. D. BroEK ${ }^{1}$ ) voor Nederland bekend werd gemaakt met de woorden: "Il est très probable que cette espèce va ce répandre peu à peu dans tout le pays (Belgique); et comme nous l'avons déjà trouvée dans la partie hollandaise du canal de Zelzaete, elle est également à ajouter à la faune malacologique de Hollande." Ook in Duitschland is zij op verschillende plaatsen in de vrije natuur ingeburgerd, nadat zij, zonder twijfel onopzettelijk, b.v. door Aquarium-liefhebbers, verspreid werd. Physa acuta heeft dus alle kans een lid van onze fauna te worden:

Dat is gelukkig aan den beruchten Colorado- of aardappelkever (Doryphora decemlineata Lay) niet gelukt. Oorspronkelijk in het verre Westen van Noord-Amerika op Solaneën levende gaf hem de toenemende aardappelbouw gelegenheid zich steeds meer oostwaarts uittebreiden, kort na $18^{\prime 7} 0$ over geheel Noord Amerika, waar hij in de oostelijke Staten groote verwoestingen aanrichtte. Overbrenging naar Europa was moeilijk, omdat kever en larve slechts van aardappelloof leven. Desniettemin kwam in $18 \% 6-1878$ een aantal exemplaren naar Europa, waar zij op enkele plaatsen in Duitschland zich vermenigvuldigden. Maar aan den schrik voor dezen gevaarlijken vijand evenaarden de verdedigingsmiddelen en spoedig bleek het gevaar geweken. Een gelijk lot is aan de St. José schildluis beschoren.

De wegen van import van dieren kunnen somwijlen zeer ingewikkeld zijn. Daarvoor slechts één voorbeeld. Door J. C. C. Loman ${ }^{2}$ ) weten wij, dat de beekprik (Petromyzon Planeri) het boveneinde der kleine Veluw-beekjes bewoont. In den darm dier prikken trof Loman den parasitischen draadworm Dacuites globosa Duj. aan, voordien slechts bekend uit de beekforel: Herhaaldelijk zijn proeven genomen om in deze beekjes forellen te teelen. Het is dus waarschijnlijk, dat zij de importeurs der parasieten zijn.

Naast den onopzettelijken invoer waarvoor boven eenige voorbeelden uit Nederland genoemd werden, heeft de mensch zich van oudsher ook opzettelijk met het invoeren van dieren bezig gehouden. Voor de huisdieren verliest zich dat in het duister der tijden. Even duister is de geschiedenis b.v. van den boschfazant (Phasianus colchicus L.), die bij ons standvogel is. Men beweert, dat hij in oude tijden geplant werd; dat beweert men ook in Engeland met de bijvoeging, dat de Romeinen het zouden gedaan hebben. ScHARFF ${ }^{3}$ ) betwijfelt dit en acht het niet onmogelijk, dat hij in Engeland een indigene vogel is, die de glaciale tijden overleefde.

Dat geldt natuurlijk niet voor andere fazantensoorten, die vaak met den boschfazant kruizen. Zij worden bij ons als jachtobjecten ingevoerd en zijn ingeburgerd, wat met de "Grouse" (Lagopus scoticus), die sedert 1893 bij herhaling op de Veluwsche heidegronden werd uitgezet, nog niet schijnt gelukt te zijn. Andere geimporteerde vreemdelingen zooals pauw, parelhoen zullen bij ons niet verwilderen en van zeldzame eenden- en reigersoorten, bij ons in het wild aangetroffen, zal een deskundige spoedig vaststellen of zij op den trek verdwaald of uit een dierpark ontsnapt zijn.

Op dit gebied zijn allerhande verrassingen te wachten. Zoo werden ontvluchte flamingos (Phoenicopterus roseus Pall.) aangetroffen, bij Leiden werd een beverrat (Myopotamus coypus)

1) E. VAN DEN BROEK, Ann: d. 1. Soc. malacolog. de Belgique V. 1870, p. 19

2) J. C. C. Loman, in Tijdschr. Ned. Dierk. Ver. Versl. (1909) 1910, p. LXII.

3) R. F. ScharfF, History of European Fauna 1899, p. 256. 
gevangen, die nit de Rotterdamsche Diergaarde ontsnapt was ${ }^{1}$ ) en bij. den Helder strandde een exemplaar van het braziliaansche waterzwijn (Hydrochoerus capybara) ${ }^{2}$ ), dat blijkbaar van een voorbijvarend schip afkomstig was. Op die wijze kwamen ook verschillende exemplaren van de Caret-schildpad (Chelonia midas) bij West-Kappelle aan het strand, die afkomstig waren van een van Antwerpeu komend amerikáansch schip, dat meerdere exemplaren overboord had doen werpen ${ }^{3}$ ).

Maar er zijn ook ontwijfelbare voorbeelden van geslaagde acclimatisatie. Wij herinneren aan de geschiedenis van de wijngaiard-slak (Helix pomatia L.). Het was in Duitschland opgevallen, dat deze slak, die in Zuid- en Midden-Duitschland algemeen verspreid is, in NoordDuitschland steeds schaarscher wordt en gebonden bleek aan oude nederzettingen. In 1888 stelde dan ook E. von Martens ${ }^{4}$ ) de vraag of zij wel in Noord-Duitschland inheemsch was. Overtuigend werd die vraag door hem en anderen in dien geest beantwoord, dat de slak eerst na Karel den Groote, met invoering van het christendom, door ridders en monniken als vastenspijs werd ingevoerd. Zoo werden burcht- en kloostertuinen de centra van waar uit de slak zich allengs verspreidde en inburgerde. Ook bij ons wijst het gelocaliseerde voorkomen (buitenplaatsen bij Haarlem, Leiden, den Haag; Buren bij Tiel, waar vroeger een klooster stond) op een soortgelijke invoer en acclimatiseering ${ }^{5}$ ). Terecht zegt daarom Henk LOTs ${ }^{6}$ ) van haar: „op de meeste plaatsen waar zij geronden werd, kan men nog nagaan, dat zij ingevoerd is geworden en later om zoo te zeggen verwilderd". Neemt men in aanmerking, dat zij in den omtrek van Haarlem "Caracolle" heet, zoo is men geneigd aan import door Spanjaarden te denken: Caracola toch is haar spaansche naam, het equivalent van het fransche escargot. Men had ook aan invoer door den Rijn kunnen denken, nademaal de slak de rotsige oevers van den Rijn boven Bonn talrijk bewoont en DARwis bewees, dat zij, door haar deksel beschermd, lange onderdompeling verduren kan. A. C. Oddenans ${ }^{7}$ ) bericht dan ook van een te Arnhem aangespoeld exemplaar. De kalkhoudende "Löss". bij Arnhem ware een goede woonplaats voor haar geweest. Maar haar wijze van voorkomen verzet zich tegen deze verklaring. Zij kan evenmin als een relict beschouwd worden, want zij ontbreekt in de jongere glaciale diluviale afzettingen en evenzeer in het Alluvium van Noord-Duitschland.

Met meer succes is de snoekbaars (Lucioperca lucioperca L.) bij ons ingevoerd. Oorspronkelijk kwam deze gewaardeerde tafelvisch in Europa slechts. voor in de Elbe en in rivieren en meeren oostwaarts daarvan, in Rusland tot in het westelijke Azië; in de Oostzee, het zuidelijk Noorwegen, Zweden en Finland, verder in het Donaugebied, in de Zwarte en Kaspische Zee, in het Aral-meer en in de daarin mondende rivieren. In 1883 in den duitschen Rijn gepoot, werd reeds in 1888 het eerste exemplaar te Milligen bij Nijmegen gevangen ${ }^{8}$ ), in 1891 een exemplaar te Waardenburg in Gelderland ${ }^{\%}$. Reeds in 1892 ontving het Kon. Zoologisch Genootschap Natura Artis Magistra een exemplaar, dat op 3 October nabij Zeeburg in de buurt van Amsterdam bemachtigd was. Sedert dien is de visch zoo ingeburgerd, dat men hem b.v. uit de buurt van Uitgeest voor comsumptie bestellen kan.

Dat andere visschen zooals de hongaarsche karper, de regenboogforel (Salmo irideus) en de dwergmeerval (Amiurus nebulosus) zich steeds meer bij ons zullen inburgeren, zij slechts aangestipt.

Met meer nadruk is er op te wijzen, hoeveel kritiek in deze materie noodig is. Maar al te licht wordt van een organisme, dat ons in onze fauna vreemd aandoet, veronder-

1) F. A. Jentink, Tijdschr. Ned. Dierk. Ver. (2) XI. 1909, Versl. p. XlIII.

2) C. Kerbert, Tijdschr. Ned. Dierk. Ver. (2) V. 1895, Versl. p. V.

3) M. WeBer, Tijdschr. Ned. Dierk. Ver. (2) III. 1889, Versl. p. XXXIII, zie ook F. A. Jentink, ibid. (2) V. 1895. Versl. p. V.

4) E. von Martens, Naturw. Wochenschr. 1888.

5) Dat Helix pomatia in Zuid-Limburg aangetroffen wordt, ligt haast voor de hand, maar is natuurlijk buiten verband met de verhouding in het overige Nederland, dat faunistisch zoo belangrijk afwijkt van Zuid-Limburg.

6) F. A. Herklots, Nat. Historie van Nederland, Weekdieren, 1870, p. 35.

7) A. C. Oudemans, Tijdschr. Ned. Dierk. Ver. (2) X. 1906, p. XXXIII.

8) C. Kerrert, Bijdragen tot de Dierk. Feestnummer 1888, p. 66. - Tijdschr. Ned. Dierk. Vereen. (2) II. Versl. Vergad. 1888, p. XXXIV.

9) A. A. van Bemmelen, Tijdschr. Ned. Dierk. Vereen. (2) III. 1892, Versl. Vergad., p. CXIII. 
steld, dat het geimporteeerd of een immigrant uit den laatsten tijd is. Daarvoor slechts drie voorbeelden:

Een zeer opmerkelijke visch is de meerval (Silurus glanis L.), niet alleen omdat hij de reus onder de europeesche zoetwatervisschen is, meer nog wegens zijn zonderlinge verspreiding. GÜNTHER ${ }^{1}$ ) duidt haar vrij goed aan met de woorden: "European rivers east of Rhine" waarbij evenwel het system van de Weser en de bëneden-Elbe uitgesloten moeten worden. Wonderlijk is nu zijn onverwacht optreden is ons land. Door Gronovios (1754) weten wij, dat hij eertijds in het Haarlemmermeer en daarmede in gemeenschap staande wateren menigvuldig was. Allengs minder algemeen, is hij sedert de drooglegging daarvan (1836) een zeldzame visch geworden, beperkt tot de wateren die vroeger met het Haarlemmermeer in verbinding stonden zooals de Ringsloot, Aalsmeer, het Kaagher rneer, de Amstelveensche plas. Reeds VALENCIENneS ${ }^{2}$ ) achtte dit geisoleerde voorkomen zoo ver van het verspreidingsgebied der soort wellicht verklaarbaar door import: "peut-être le poisson $y$-at-il été transporté, comme dans quelques uns de cenx (sc. lacs) de Suisse". A. A. van Bemmelen ${ }^{3}$ ) zegt: "De meerval is ook waargenomen in het Uddeler-meer (tusschen Garderen en Apeldoorn) in Gelderland; in 1825 werd aldaar een groot individu gevangen; door een visscher in de nabijbeid van dat meer woonachtig is mij verzekerd, dat er later nog meer gezien waren; deze voorwerpen zouden daarin echter uit Hongarije overgebracht zijn, ten tijde van Prins Willem V". Ladterborn ${ }^{4}$ ), deze overlevering releveerende, voegt hieraan toe: „Eine ähnliche schon früher erfolgte künstliche Einbürgerung hat auch für den Wels des Haarlemer Meeres mehr Wahrscheinlichkeit für sich als etwa die Annahme einer Einwanderung des Fisches vom Hochrhein her, als dieser noch mit der Donau in Verbindung stand".

Wie de Veluwsche heidemeertjes kent zal het voorkomen van den meerval in het Uddeler-meer inderdaad slechts door import verklaren. Evenwel zal men het - de toen-. malige verkeersmiddelen in aanmerking nemende - waarschijnlijker achten, dat de visch dan uit het Haarlemmermeer werd overgebracht, althans uit een der zwabische of beiersche meeren, die met de Donau (het speciale woongebied van den meerval) in verbinding staan. Op die wijze ook zijn voorkomen in het Haarlemmermeer te verklaren is voorzeker het allerlaatste redmiddel. Zoodanige veronderstelling verliest uit het oog, dat de meerval, behalve in het meer van Constanz, wel degelijk ook in den duitschen Bovenrijn bij en beneden Basel, al is het ook maar een enkele maal, gevangen werd ${ }^{5}$ ). Aan den anderen kant is het waar, dat de meerval althans tegenwoordig in het Wesergebied ontbreekt en juist de Weser was het, die waarschijnlijk bij het terugtrekken van het landijs tijjelijk westwaarts over Nederland haar water uitstortte. Maar voorhands wil het mij voorkomen, dat de meerval een relict is uit tijden van een grooter verspreidingsgebied ook over het westelijk gedeelte der noordgermaansche laagvlakte. Dit kont mij waarschijnlijker voor dan import of de veronderstelling, dat hij uit de Donau tot ons kwam, toen deze in diluvialen tijd tijdelijk met den Rijn in verbiuding stond.

De geschiedenis van de moerasschildpad (Emys orbicularis) maant al evenzeer tot voorzichtigheid in het nemen van besluiten, waarbij men de gemakkelijke verklaring van import te hulp roept. Sedert 1897 is zij in Limburg in talrijke beekjes, moerassen en sloten, die direct of indirect met-de Maas samenhangen, gevonden, eveneens in het onmiddellijk aangrenzende gebied van Pruissen "). Die vindplaatsen werden steeds talrijker naar mate men er op ging letten en toonen overtuigend aan, dat althans voor het Maasgebied de oorspron-

1) Günther, Cat. British Museum, fishes 'v. 1864, p. 32.

2) Cuvier \& VALENCiennes, Hist. nat. poissons XIV. 1839 , p. 340

3) A. A. van Bemmelen, Bouwstoffen voor eene fauna v. Nederland III. 1866, p. 357.

4) LaUterborn, Die geograph. u. biolog. Gliederung d. Rheinstroms, Sitzber. d. Heidelberger Akad. d. Wissenschaften III. 1918 , p. 74 .

5) v. SIEBold, Süsswasserfische v. Mittel-Europa 1863, p. 81.

6) Zie vooral H. Scmmitz, Tijdschr. Ned. Dierk. Ver. (2) VIIl. 1904, p. 104 en C. Willemse in „de Levende Natuur" XXI. 1917, p. 126. 
kelijke opratting, dat alleen van ingevoerde of uit aquaria ontsnapte exemplaren sprake kon zijn, niet meer steekhoudend is. Dat kon aanvankelijk nog eenigszins aannemelijk zijn voor het exemplaar, dat in 1893 in de Hornespolder bij Katwijk ${ }^{1}$ ' gevangen werd; nauwelijks meer toen vervolgens in de Haarlemmer trekvaart bij Amsterdam ${ }^{2}$ ), aan de Waalsdorper weg bij 's Gravenhage (A. C. Oddemans volgens C. Willemse 1. s. c.) en in Groningen' in het Storterhuistermeer ${ }^{3}$ ), een oud riviertje, verdere exemplaren aangetroffen werden. Gezien de verborgen leefwijze der schildpad, gezien de afgelegenheid van de meeste van deze vindplaatsen, wordt het in het licht van de talrijke vondsten in Limburg meer dan onwaarschijnlijk, dat het zich hier steeds om ontsnapte exemplaren zou gehandeld hebben. Wij zullen niet mistasten, als wij aannemen met een relict te doen te hebben uit een veraf gelegen tijd, toen de schildpad een ruimere verspreiding had ook ten oosten van ons land. Daarvoor pleit, dat zij thans nog sporadisch in Westfalen voorkomt en als subfossiel in de venen in Zuid-Zwęden, Denemarken, Zwitserland en vele streken in Duitschland, waar zij allengs uitgestorven is. $\mathrm{Zij}$ is trouwens ook uit het pleistoceen van Engeland bekend.

In de derde plaats noem ik den hamster (Cricetus cricetus L.). Import is bij hem natuurlijk uitgesloten. Daar hij in faunistische geschriften eerst sedert 1880 uit Limburg genoemd wordt, neemt men vrij algemeen aan, dat hij een immigrant van de laatste tientallen yan jaren uit het naburige Duitschland b.v. uit de omgeving van Aken, zou zijn.

Dit is nauwelijks een bewijs; het laat zich gemakkelijk verklaren, door de vroegere opmerkelijk geringe belangstelling in ons land voor de studie der in 't wild voorkomende gewervelde dierey, behalve vogels. Wilde men de gewraakte redenatie tot uitgangspunt nemen, men zou tọt vreemde uitkomsten komen. Om slechts enkele voorbeelden te noemen, zoo kent men de te noemen gewervelde dieren eerst sedert de bijgevoegde jaartallen als leden onzer fauna: moerasschildpad (Emys orbicularis L.) 1897 ; de salamanders Molge alpestris Laur. en M. palmata Schreib. 1875; de knoflookpad (Pelobates fuscus) 1898; de vroedmeestejpad (Alytes obstetricans) 1893; de wijdverspreide heikikvorsch (Rana arvalis Nilss.) 1878; de hazelmuis (Muscardinus avellanarius L.) en de eikelmuis (Eliomys quercinus L.) 1898.

Niemand zal willen beweren, dat al die dieren immigranten zijn uit den laatsten tijd!

Het voorkomen van den hamster laat zich dan ook, zooals wij later zullen zien, minder gekunsteld verklaren.

Wij hebben boven enkele dieren (wijngaardslak, snoekbaars e.a.) leeren kennen, waardoor onze fauna in historischen tijd verrijkt werd; groot is hun aantal niet; het verdwijnt tegenover de verarming, die zij onderging.

Oudtijds waren zonder twijfel de hooger gelegen deelen van Nederland - daargelaten het diluviale heuvelterrein, dat wel, evenals thans, met heidevelden en verspreide sparren en eikenstruiken begroeid was - met loofbosch bedekt. Hieraan sloot zich het lage gebied aan met uitgestrekte meren, plassen, moerassen, venen, kortom stilstaande wateren verschillend in afmeting, bodem en plantengroei; het werd doorstroomd door rivieren en tallooze waterloopen, die aan ongeregelde overstroomingen bloot stonden.

Oude berichten en vondsten, en in niet mindere mate het onderzoek der terpen en wierden, dat onder de bekwame leiding van Dr. A. E. van GlFren, tot zulke belangrijke uitkomsten geleid heeft, toonen aan, dat in de eerste helft onzer jaartelling oeros, eland, edelhert, bruine beer, wild zwijn, wolf, bever e.a. Nederland bewoonden. Daarvan is slechts edelhert en wilde zwijn, die vroeger tot in de zeeprovincies voorkwamen, overgebleven. Het wilde zwijn, thans weer ingevoerd, recruteerde zich voordien gedurende de laatste 50 jaren in hoofdzaak wel uit overloopers uit Duitschland. Zoo is het ook met den wolf. Vroeger zoo algemeen, dat drie, vier eeuwen geleden de bevolking, zelfs in de buurt van Amsterdam, nog tot, de jacht opgeroepen werd ${ }^{4}$ ), is het niet mogelijk een jaartal op te geven voor den laatsten

1) J. Th. Oudemans, Tijdschr. Ned. Dierk. Ver. (2) IV. 1893, p. XXIII.

2) E. Heimans, De Levende Natuur IX. 1905, p. 53.

3). H. van Zanten, in de Levende Natuur XIV. 1909, p. 99.

4) R. F. Maitland. Notices sur les animaux rares des Bays-Bas 1898, p. 4 . 
indigenen, wolf. De zeer enkelen, die bij ons geschoten zijn, zooals in 1891 tusschen 's Hertogenbosch en Tilburg, zijn overloopers; die in strenge winters uit de Ardennen en over de Kleefsche bosschen tot in het oosten van ons land afdwaalden. De laatste bever werd omstreeks 1801 dicht bij den IJssel geschoten ${ }^{1}$ ).

Niet minder was de verarming in de vogelwereld. Maar zij was meer van numerieken aard al zijn enkele vogels, zooals de kwak ( $N$ ycticorax nycticorax L.), nagenoeg tot uitroeiing gekomen. Vooral wáter- en moerasvogels verloren door de uitgebreide droogleggingen hun woon- en broedplaatsen. Zoo vertelt ons Peut Lechner ${ }^{2}$ ) hoe het voormalige Zevenhuizensche Bosch in de buurt van Rotterdam een beroemde broedplaats was van lepelaars, kwakken, reigers, schollevaars. Reeds lang is dit vogeldorado verdwenen; met anderen is het evenzoo gegaan. En terwij] vroeger de vogeloorden in ons waterrijk land in Europa alleen nog maar in het Donaudelta hun evenknie vonden, moeten wij thans dankbaar zijn, dat nog enkele "natuurmonumenten" en beschermde wateren, zooals het Zwanewater in Noord-Holland, ons herinneren aan den voormaligen rijkdom.

Maar de invloed van den mensch beperkte zich niet tot ontbossching en drooglegging. Juist in onzen tijd zien wij hoe ook de hooge en lage diluviale gronden meer en meer in cultuur genomen err veranderd worden. Enkele cijfers maken dit duidelijk. De „woeste gronden" besloegen b.v. in Gelderland in 1833 nog 165.000 H.A, in 1912 was dit cijfer gedaald tot 92.000 H.A. Voor geheel Nederland waren die cijfers $90 \% .000$ respectieve 524.000 H.A. In 1833 maakten de woeste gronden nog $2 \% .9 \%$, in 1912 slechts $16.08 \%$ van het totale landoppervlak uit ${ }^{3}$ ). De invloed van een en ander op de fauna behoeft geen nader betoog.

Maar ook op andere wijze grijpt de mensch in.

De „correctie" der rivieren, bij name van Rijn, Maas, IJssel en bijbehoorende waterwegen; bracht ingrijpende veranderingen in hun stroom, bodem, schuilplaatsen e.d.m. te weeg, die niet zonder invloed bleven op zalm, elft, steur, wier aantal ziender ooge afneemt. De vervuiling door fabriekswater vernietigt de fauna in beken, vaarten en slooten; de Geldersche beken b.v. leveren daarvoor het eclatante bewijs. De Eerbeek b.v. huisvestte vroeger blijkbaar zoo talrijk den rivierkreeft, dat in de 1\%de eeuw in het "Markenboek" de bepaling genotuleerd werd, waarbij het op hooge straffe verboden werd weren in de beek te maken om kreeften te vangen. Toenmaals waren zij nog zoo talrijk, dat het de moeite loonde, strafbepalingen omtrent hun vangst te maken, thans zijn zij uit de vervuilde Geldersche beken verdwenen.

In de voorafgaande beschouwingen zijn van verschillende gezichtspunten uit waaronder men eene fauna beschouwen kan, heel wat dieren ter sprake gekomen, die heden in Nederland worden aangetroffen. Soms kwam daarbij ook reeds een historisch moment op den voorgrond. Om evenwel de fauna juist te begrijpen, moet cursorisch een blik geworpen worden op hare geschiedenis zooals geologie en palaeontologie haar leert.

Terecht heeft KовELт opgemerkt, dat men er niet aan denken zou de hedendaagsche. noordeuropeesche fauna van de jong-tertiaire af te scheiden als niet de ijstijd en het optreden van den mensch ingegrepen hadden in de levensvoorwaarden der dieren en deze grondig. veranderd hadden.

Op het hoogtepunt van den ijstijd ${ }^{4}$ ), was Nederland ten Noorden van den Rijn door landijs overdekt. Of die ijsbedekking dik of dun, gesloten of hier en daar onderbroken was; is, zoologisch gesproken, van geringe beteekenis; zij moet de bestaande dierenwereld.in

1) Hier is wellicht de plaats eene vergissing recht te zetten. Een teekening van den kop van een walrus, door A. DürER tijdens zijn reis in Nederland (1521) gemaakt $a$ ) met de schriftelijke bijvoeging, dat hij gevangen was ,in der niederländischen See", heeft KILlERMANN $b$ ) tot de veronderstelling gebracht, dat toenmaals de Walrus in de Noordzee voorkwam en een ex. aan de kusten van Nederland, "veischlagen" werd. Dit komt mij geheel onwaarschijnlijk voor; trouwens de teekening van DüreR maakt niet den indruk vervaardigd te zịnn naar een versch exemplaar; vermoedelijk naar een in zout bewaarden of opgezetten kop, die door ijszeevaarders naar Nederland was meegebracht.

a) Gereproduceerd b. v. in "Albrecht Dürer" schriftlicher Nachlass” herausgegeben von . E. HeydrICH, Berlin 1908, p. 80.

b) KILlermann, Naturw. Wochensehrift XXVII. 1912, p. 785

2) A. A. van Pelt Lechner, Ardea VII., p. 99.

3) Ontleend aan R. SchuILING: Nederland 1915, p. 548.

4) Voor ons doel is het voldoende haar als een eenheid te beschouwen. 
hoofdzaak praktisch vernietigd hebben. Een land immers, waarvan de oppervlakte toen reeds uit rivier-sedimenten was opgebouwd, kon moeilijk aan dieren refugiën aanbieden zooals de ijsvrije "noenataks", die boven het groenlandsche landijs uitsteken of soortgelijke rotsen, die boven het gletscherijs in Zwitserland zich verheffen.

Weliswaar onderging het ijsvrije land bezuiden den Rijn niet zulk eene vernietiging zijner fauna, toch stond ook zij onder den invloed van het naburige landijs. De korte zomer zal slechts aan dieren, bestand tegen lage temperatuur, koude winden en sneeuwbuien, een moeilijk bestaan gegeven hebben. In het Westen eindelijk, in het gebied onzer zeeprovinciën, bood een "Haff" van reusachtige afmeting achter de toenmalige duinreeks en voor het overige amphibiotisch land slechts aan moeras- en watervogels een goed onderkomen.

Met eenige phantasie kan men zich ongeveer een beeld vormen van de althans aan soorten arme fauna.

Eerst met het smelten van het landijs en met de daarmede gepaard gaande geleidelijke verhooging der temperatuur ontstonden betere levensvoorwaarden. Maar in een delta-land als het onze, kwamen nieuwe moeilijkheden voor de dierenwereld. De tijd der "groote wateren" brak aan; het smeltwater van ijs en sneeuw zal de waterloopjes in beken, de beken in rivieren, de rivieren in geweldige stroomen verkeerd hebben.

De hooger gelegen terreinen, ijsvrij geworden en allengs met heide zich bedekkende, waartusschen dennen- en eikenstruiken zich geleidelijk vestigden, boden het eerst een veilige woonplaats. Zij hebben voor een goed deel dit karakter bewaard en daarmede ook menig dier, dat ons nog herinneren kan aan dien arktischen en subarktischen tijd. Al tornt men tegenwoordig, vaak met spitsvondigheid, aan den naam, het kan vauwelijks tot misvatting aanleiding geven, als wij deze arktische en subarktische achterblijvers glaciaal-relicten noemen. De "stenothermen" onder hun, degenen dus, die slechts geringe temperatuurschommelingen verduren kunnen, zijn zeker voor een goed deel onder de toenemende temperatuur bezweken, of zij moesten het afleggen tegenover immigranten, die door de betere levensvoorwaarden ook naar de heidevelden getrokken werden. Maar vooral het zoete water: de beekjes en voornamelijk de heideplassen hebben menig relict voor ons bewaard. Voortgezette studie der levensgemeenschappen op wat wij gewoon zijn diluviale gronden te noemen, zal eerst kunnen ontleden, welke elementen de oudsten zijn, welke van jongeren datum.

Van die relicten willen wij enkelen noemen.

Een zekere vermaardheid heeft de platworm Polycelis cornuta vooral in Duitschland gekregen. Gedurende den laatsten ijstijd waren vermoedelijk alle stroomende wateren in Noord- en Midden-Duitschland door den platworm Planaria alpina bewoond. Daar haar optimale temperatuur bij $5^{\circ}-6^{\circ} \mathrm{C}$. ligt, moest zij bij de stijging der temperatuur allengs in den bovenloop der koude beken zich terugtrekken. Zij werd daarbij gevolgd door een tweede stenotherme koudwater-vorm Polycelis cornuta, die echter hoogere temperaturen verduren kan en ten slotte in warmer geworden beken de Planaria alpina verdrong om zelf het brongebied te bevolken. Eerst in historischen tijd schijnt een derde soort: Planaria gonocephala, die een eurytherme warmwater-vorm is, dus ruime temperatuurverschillen verdragen kan, in den benedenloop der beken ingedrongen te zijn, vanwaar zij zich stroomopwaarts verbreidde.

Regelrecht bewonen dus in de aangeduide volgorde de 3 Planariën de beken van oorsprong tot monding, overeenkomstig de toenemende verhooging der temperatuur van de beek en de toenemende temperatuur-optima der 3 Planariën ${ }^{1}$ ). Voor de Alpenplanarie schịnt ook het brongebied onzer beken sinds den ijstijd te warm geworden te zijn: zij ontbreekt er althans, maar Polycelis cornuta wordt nog in den bovenloop der beken aangetroffen. Het eerst in 1907 in de Eerbeek ${ }^{2}$ ), sedert dien door Dr. Romisn in de Heusenbeek te Voorbeek (L.), in de Zwanenspreng bij Apeldoorn, in de Sprengenbeek bij Beekhuizen (G.) en onlangs in beekjes bij Oosterbeek.

1) Vorgt, Zool. Jahrb. Abt. Systematik VIII. 1895, p. 131. - Thignemand, Internat. Revue d. Hydrobiologie 1912. 2) Max Weber, Tijdschr. Ned. Dierk. Ver. (2) X. 1907, p. XX. 
Treffender nog is het optreden van noordelijke vormen in eigentlijke heideplassen.

Bovenaan staat de zoetwatervloo Eurycercus glacialis Lilljeb., die bekend is van het arktische gedeelte van Rusland en Noorwegen, van Groenland, van het Behring eiland en sedert 1912 uit ons land van Acht (Noord-Brabant), van de Gosselsche heide bij Grave, uit de groote heideplas Gerritsflesch bij Hoog Buurlo (Gelderland) ${ }^{1}$ ) en uit het afgelaten ven bij Woensdrecht (Dr. Romijn).

De heideplas Gerritsflesch bevat verder als eenige Dytiscus-soort Dytiscus lapponicus Gylh., eene soort inheemsch in Scandinavië, Denemarken en Noord-Oost-Duitschland. Deze watertor werd een aantal jaren geleden bij ons bij Lochem ontdekt, daarop in $191 \%$ in een heideplas bij Loenen op de Veluwe. Juist bleek (in 1918) mijn voorspelling, dat hij ook in Geriritsflesch zou voorkomen. Ik haal dit slechts tot staving aan van ons betoog. Immers als eene voorspelling; gebaseerd op combinatie van onderstellingen, juist blijkt, pleit dit ook voor de juistheid dier onderstellingen.

Vermoedelijk mogen wij ook het "schrijvertje" Gyrinus minutus F. onder de glaciaalrelicten rekenen. Zoo zullen er onder de insecten wel meer zijn,. LaUTER Born noemt b.v. de libelle Somatochlora arctica.

Ook de lage landen herbergen getnigen uit den vroegen post-glacialen tijd, toen MiddenEuropa bewoond werd door een gemengde fauna van bewoners der subarktische steppen en tundras en van alpine soorten. Daarbij behoorde Microtus ratticeps Keys \& Blas., een woelmuis, die thans nog aangetroffen wordt in het noordelijk gedeelte van het continentale Europa en Azië: van Noord-Rusland en het gebergte van Scandinavië oostwaarts tot Siberië, zuidwaarts tot noordelijk Hongarije en oostelijk Noord-Duitschland en in 1835-1836 in een "muizenjaar" ook in Lisse bij Leiden gevonden werd ${ }^{2}$ ).

Voor het overige zal eene postglaciale steppentijd, zooals wij haar _ om in de buurt te blijven - van den Middenrijn tusschen Bonn en Mainz kennen, in Nederland met zijn zeeklimaat moeilijk tot ontwikkeling hebben kunnen komen. Maar als wij aannemen, dat het "Löss", dat in Limburg en als smalle strook langs de veluwsche heuvelreeks van Doorwerth tot Dieren wordt aangetroffen, een aeolische vorming is, dan wijst dat althans op eenen droogeren tijd, waarvan vormen als Microtus ratticeps en voorts de boven (p. 184) besproken hamster gebruik konden maken zich te vestigen. Beiden zijn dan relicten, die zich vroeger in eene grootere verspreiding verheugden. Dat daarvoor tot heden de palaeontologische bewijzen ontbreken, is niet verwonderlijk. Uit de uitstekende studie van Rorres ${ }^{3}$ ) over de diluviale zoogdieren in Nederland is duidelijk gebleken, hoe gebrekkig de tot ons gekomen resten getuigenis afleggen van den rijkdom dier fauna. Kleinere zoogdieren ontbreken daarin geheel en van arktische zoogdieren, waarvan wij gerust mogen aannemen, dat althans enkelen in Nederland hebben geleefd, is niets tot ons gekomen, als schrale resten van het rendier. Dat ligt voor een goed deel aan de geringe ontwikkeling van fijnkorrelige afzettingè, maar ook aan de schaarschte van onderzoek aan die lagen besteed.

De terpen kunnen die leemte slechts voor een deel aanvullen. Hun geschiedenis reikt niet ver genoeg terug en door hun ligging in het overstroomingsgebied van zee en rivier, konden zij van kleine zoogdieren slechts die bewaren, die in dit vochtige terrein leven konden.

Het is niet altijd duidelijk waarom relicten, zooals b.v. de bovengevoemde, die reeds zoo lang in Nederland gevestigd zijn, geen ruimere verspreiding gekregen hebben. Er is evenwel hierbij piet uit het oog te verliezen, dat uit het negatieve feit van onbekendheid nog niet het ontbreken eener soort behoeft te volgen. Een treffend voorbeeld hiervoor is de heidekikvorsch (Rana arvalis Nilss.), die eigen is aan de heide- en veengronden en aan de toendren van het palaearktische gebied.

In 1878 in Nederland het eerst in de buurt van Apeldoorn ontdekt, werden sinds dien telkens nieuwe vindplaatsen opgegeven. In de eerste plaats uit de heidestreken vanwaai'

1) N. L. Wibautr-Isebrèe Moexs, Tijdschr. Ned. Dierk. Ver. (2) XII. 1913, p. 227.

2) F. A. Jentink, Tijdschr. Ned. Dierk. Ver. V. 1881, p. 105.

3) L. Rutren, Die diluvialen Saügetiere d. Niederlande 1909. 
E. Heimans, die zooveel bijdroeg tot de kennis omtrent dezen kikvorsch, hem terecht heikikker doopte. Daar hij sedert 1895 van Texel bekend is en ik hem in 1916 ook in de duinen van het eiland Schouwen aantrof, dus in aeolisch, uit de zee geboren zandgrond, blijkt daaruit zijn wijde verspreiding in Nederland en toch is de kennis daarvan eerst sedert 40 jaren heel geleidelijk verkregen. Zoo ging het ook met Planaria gonocephala en met andere soorten kan hetzelfde gebeuren.

Den draad der geschiedenis der fauna, dien wij ter wille van de glaciaal-relicten afbraken, weder opvattende, mogen wij aannemen, dat voor haar allengs weer normale toestanden terugkeerden en behalve de hooge gronden ook het overige land algemeen bewoonbaar werd. Allereerst kon zich verder ontwikkelen, wat van de vroegere fauna nog aanwezig was, maar daarnaast opende zich de gelegenheid tot immigratie.

De geographische ligging van Nederland wijst 3 wegen aan, waarlangs zij kon plaats hebben.

1. In het Oosten staat Nederland wijd open voor de bewoners der noordduitsche laagvlakte, die in plantengroei, temperatuur en andere klimatische factoren er nauw mede samenhangt. Ongetwijfeld recruteerde zich het hoofdcontingent onzer fauna uit dit gebied. De noordduitsche laagvlakte is van haar kant een onderdeel van het zoogenaamde boreale gedeelte der palaearktische fauna, waarmede het. voornaamste karakter der nederlandsche fauna voldoende gekenmerkt is.

2. In het zuidoosten opende zich de poort voor de invasie van "rhenane" elementen, die door (aanspoelsel) of langs den Rijn plaats greep.

Onze zuidelijkste provincie Limburg, die faunistisch zoo zeer afwijkt van het overige land, dankt dat zeker voor een goed deel daaraan, dat blootliggend rotsgesteente en daarin ingesneden valleien met stroomende beekjes, verscheidenheid dus van den bodem en daarmede van het plantenkleed, afwijkende en voor menig dier gunstige levensvoorwaarden scheppen. $\mathrm{Zij}$ is een noordelijke uitlooper der "gallo-rhenane" fauna. Opmerkelijk uit zich dat in de insectenwereld, maar ook hoogere vormen, zoouls de boven genoemde zoogdieren Muscardinus avellanarius L. en Eliomys quercinus L. (zie boven), voorts vormen als de vuurpad Bombinator pachypus ${ }^{1}$ ) leggen daarvan getuigenis af.

3. Moeilijk van de vorige groep te scheiden is een element, dat wij atlantisch kunnen noemen en ongeveer beantwoordt aan wat SCHARFF als "lusitanisch" element in de europeesche fauna aangeduid heeft. Hij noemt daarvoor speciaal de lijster Melizophilus undatus; de landmollusken Geomalacus maculosus en meerdere Testacella-soorten e. a.

Deze dieren ontbreken in onze fauna. Maar het wil mij voorkomen, dat b.v. de volgende als representanten van dit van oorsprong zuidelijke fauna-element gerekend mogen worden. De kwikstaart Motacilla alba lugubris; de vroedmeesterpad (Alytes obstetricans) en de watersalamander Molge palmata Schneid. ${ }^{2}$ ). Van verdere zoetwaterbewoners noem ik nog de zeer opmerkelijke Caridina desmaresti Millet. Deze kreeft, die algemeen verspreid is in het zoete water van zuidwest Europa en noordwest Afrika, werd in 1886 in de Maas bij Hestière (België), als het noordelijkste voorkomen, gevonden. In 1915 deelde Juffrouw DE LinT ${ }^{3}$ ) mede hem in het Abcouder Meer aangetroffen te hebben, in 1916 vond vaN Der SLeen ${ }^{4}$ )

1) In tegenstelling met Bombinator igneus, die in het faunagebied van de noord- en oosteuropeesche laaglanden behoort.

2) Ook mij kumt de wel eens uitgesproken veronderstelling juist voor, dat Molge alpestris een relict zou zijn uit den tijd toen ons land evenals het naburige noordduitsche laagland met bosschen bedekt was. Heden ten dage gebonden san het heuvel- en lage bergland vooral van Middeneuropa, ontbreekt Molge alpestris in de noordduitsche laagvlakte, behalve verspreide vindplaatsen in noordwest Duitschland en in het Oosten van Nederland. Deze watersalamander zou dan bij die groep van relicten behooren, die zooals de lepelaar (Platalea leucorodia) en het baardmannetje (Panumus biarmicus), resten zijn van een vroegere uitgebreidere verspreiding, die ten aanzien der genoemde vogels, ingekrompen is in hoofdzaak tot een voorkomen bij ons en in de ver afgelegen Donaumionding en de zuid-russische steppenmeeren. Dat is eene opvatting, die ook reeds door LAUTERBonN in zijn voortreffelijk opstel (Die geograph. Gliederung des Rheinstroms, 1918) uitgesproken is.

3) DE LiNT, Tijdschr. Ned. Dierk. Ver. (2) XIV. Versl. Vergad. 1915, p. XCI.

4) vaN DER SteEn, ibid. (2) XIV. Versl. Verg. 1916, p. CI. 
hem in het Merwede-kanaal bij Nigtevegt en G. Romys in de Zuid-Willems-vaart bij 's Hertogenbosch.

Het moge volstaan er op gewezen te hebben, dat ook de Insecten „atlantische" representanten tellen. Zoo noemt EverTs ${ }^{1}$ ) een aantal kevers vooral van het strand van ons. land, die in zuidelijker streken thuis behoorende, langs de kusten van Duitschland onbekend zijn. Hij schrijft dat toe aan den meer directen invloed van den golfstroom; en Uy TTENBogaART ${ }^{2}$ ) beschouwt de provincie Zeeland coleopterologisch als uiterste uitlooper van het westereuropeesche subtropische gebied. Verder vermeldt Lauterbons uitdrukkelijk enkele hierbij behoorende Libellen.

Wij zullen later zien, dat ook de marine vischfauna een àntal hierbij behoorende soorten bevat, zooals Hippocampus hippocampus (L.), Pelamys sarda (Bloch.), Cantharus cantharus (L.) e. a. Van lagere vormen noem ik nog de in het zand gravende Decapode Calianassa subterranea. Het is een uitgesproken zuidelijke kreeft, die reeds van de Belgische kust en een enkele maal van de kust van Oost-Friesland, waar hij zijn noordgrens schijnt te bereiken, opgegeven was. Sedert Juni 1912 kennen wij hem ook van de kust van Texel ${ }^{3}$ ) In hetzelfde jaar werd een andere beslist zuidelijke kreeft: Portunus arcuatus voor het eerst met zekerheid en wel dwars van Koog op Texel gevangan ${ }^{4}$ ). Wellicht behoort hierbij ook Mysis kervillei G. O. Sars, het eerst uit de Seine-monding vermeld, daarna door HökK ${ }^{5}$ ) van de Oosterschelde en ten noordwesten van Terschelling. Deze steurkrab is ook uit de Zuiderzee bekend ${ }^{\circ}$ ).

Het is aan toekomstige studie voorbehouden deze slechts vluchtig aangeduide drie elementen, die, verschillend van herkomst, onze fauna samenstellen, verder te ontleden. Bij de geringe afmeting van het onderhavige faunagebied, zal die ontleding daarin haar grootste moeilijkheid ondervinden, dat het bezwaren oplevert, den localen invloed vooral van de bodemgesteldheid en daarmede van het plantenkleed uitteschakelen.

4. Onze beschouwingen zouden onvolledig zijn, als wij geen acht sloegen op een vierden toegangsweg, die voor immigratie wijd openstaat, en wel de zee, die onze lange kustlijn bespoelt.

Boven werden reeds verschillende dieren genoemd, die langs dien weg tot ons gekomen zijn: Corambe, Teredo megotara, Petricola, enkele uit het zuiden tot ons gekomen Crustaceen en visschen, wellicht ook anderen. Maar groot is hun aantal niet en het zijn bewoners van het kustwater of het strand.

Dat de zeeweg een moeilijke, ja in de meeste gevallen een voor landdieren onbegaanbare is, werd reeds boven betoogd. Zien wij af van de reeds besproken soorten, die in het binnenruim van schepen en met hun ladingen tot ons komen en beperken wij ons voorts tot de passieve immigratie, die gebruik maakt van zeestroomingen, drijfhout en andere drijvende voorwerpen zooals wieren, zeegras, de bekende zoo veelvuldig aan onze kust aangespoelde hoogovenslakken van Middelsbro en Clarence in Schotland e.d.m., dan zal wel over zee nauwelijks iets tot ons gekomen zijn, dat op het land of in het zoete water zijn woonplaats heeft.

- Wel zijn er eenige visschen te noemen, die ter wille van hun voortplanting, uit zee komende, onze riviermonden binnendringen om zooals de zalm (Salmo salar L.), het schotje (Trutta trutta L.), de houting (Coregonus oxyrhynchus L.), de elft (Alosa alosa L. p.p.), de fint (Alosa finta Cuv.), de zeeprik (Petromyzon marinus L.), de steur (Acipenser sturio L.) den Rijn, de Maas, den IJssel hooger op te stijgen.

Omgekeerd begeeft zich de geslacbtsrijpe aal (Anguilla anguilla L.) uit de rivieren en een gedeelte van het kustwater naar zee, van waar dan het jonge broed weer terugkeert. Hieraan sluiten zich andere trekvisschen aan, die een gedeelte van hun leven eveneens

1) Ev. EverTs, Coleoptera, welke het meer Zuid. Kustgebied ... bewonen etc. Entomolog. Berichten No. 20, 1904, p. 179.

2) D. L. UуттеnвoogaART, Die Coleopterenfauna der Niederlande. Coleopterolog. Rundschau 1912, Heft VI-VII.

3) J. J. Tesch, Tijdschr. Ned. Dierk. Ver. (2) XII. 1912, Versl. Vergad., p. LXXXVIII.

4) J. J. Tesch, 1. s. c.

5) P. P. C. Hoek, Tijdschr. Ned. Dierk. Ver. (2) I. Versl. Vergad. 1885, p. CXXV.

6) VAN GOoR, ibid. (2) XV. 1917, Versl. Vergad., p. XXIII. 
in onze territoriale wateren zoek brengen. Evengoed immers als wij aan de landzijde ons faunagebied door de politieke landsgrens afbakenen, - voorzeker, zoologisch gesproken, een geheel kunstmatige grens, - zoo zal aan de zeezijde de thans nog gebruikelijke politieke demarcatielijn van 3 zeemijlen, die het territoriale water tegenover de vrije zee afgrenst, de eveneens geheel kunstmatige grens van onze litorale fauna vormen.

Onder bovenbedoelde visschen behooren de ansjovis, de Zuiderharing ${ }^{1}$ ), de bot, die de Zuiderzee verlaat om zich in de Noordzee voort te planten waarna de jonge individuën weer naar de Zuiderzee terugkeeren ${ }^{1}$ ), de snotdolf (Cyclopierus lumpus. L.) e.a.

Minder bekend is, dat evenals bij de vogels, zoo ook onder de visschen verschillende gasten zijn, die ons slechts sporadisch bezoeken, voorts een aantal -verdwaalden, die niet in onze fauna thuis behooren, waartegen anderen, die daarvoor te boek stonden, wel degelijk blijken bij de nederlandsche fauna gerekend te mogen worden.

Daar, voor zoover mij bekend, hierop nimmer bepaaldelijk acht geslagen werd, moge een korte samenstelling van de mij bekend geworden gevallen volgen. De nederlandsche vindplaatsen zijn daarin opgenomen en het normale voorkomen der soorten:

1. Scombresox saurus (Walbaum), 28 November 1909 aan den Helderschen dijk 13 exemplaren [H. C. REDEKe, Tijdschr. Ned. Dierk. Ver. (2) XII. Versl. vergad. Jan. 1910, p. III]. Vroeger niet van onze kust opgegeven. Verspreiding: Atlantische kusten van Europa, Afrika en Noord-Amerika.

2. Hippocampus hippocampus (L.) (H. antiquorum Leach). Mei 1901 één exemplaar gevangen door garnalenvisschers bij Vlissingen en in den zomer van 19051 exemplaar in de Deurloo, een der zeegaten naar de Westerschelde; twee verdere exemplaren in het daarop volgende jaar in hetzelfde water [C. Kerbert, Tijdschr. Ned. Diërk. Ver. (2) VII. Versl. vergad. 1902, p. XXXIX en ibid. (2) X. Versl. vergad. 1905, p. III en 1906, p. XXII]. Hieruit blijkt, dat het zeepaardje, bekend van de Middellandsche zee en van de atlantische kusten van Europa tot Engeland als noordelijkste punt, ook bij de nederlandsche fauna behoort.

3. Raniceps raninus (L.), 24 October en 8 November 1883 telkens een exemplaar van Nieuwediep [C. Kerbert, Tijdschr. v. d. Dierk. V. 188t, p. 18]; 22 September 18841 ex. en 4 ex. 9 October 1885 van dezelfde vindplaats en 1 ex. 1 April 188\%, haven van IJmuiden [C. Kerbert, Bijdragen tot de Dierkunde, Feestnummer 1888, p. 84]. Maart 1892 een ex. gevangen in een garnalenkor even buiten het Schulpengat [Hoki, Tijdschr. Ned. Dierk. Ver. (2) III. Versl. vergad. 1892, p. CXXI.] Een verder exemplaar van onze kust vermeldt $M_{\Delta X}$ Weber l.c. Deze soort, eigen aan de Oostzee, de kusten van Scandinavië en Engeland en zeer zelden aan de fransche kust, mag dus wel bij de nederlandsche fauna gerekend worden.

4. Lampris luna (L.), 1822 een exemplaar aan de kust ran Groningen [B $\mathrm{B}_{\mathrm{AKKER}}$, Osteographia piscium 1822]; 1836 een exemplaar te Noordwijk gestrand [Jentrnk, Tijdschr. Ned. Dierk. Ver. (2) II. Versl. vergad. 1888, p. LXVIII]; 1840 een exemplaar door Noordwijksehe visschers in den Buitenlek gevangen [A. A. van Bemmelen, Bouwstoffen Fauna v. Nederland III. 1866, p. 336]; 1888 een exemplaar „nabij onze kust gevangen" [JENTINK, l.c.]. 1891 een exemplaar "aan de hollandsche kust gevangen" [A. A. va Bemmenen, Tijdschr. Ned. Dierk. Ver. (2) IV. Versl. Vergad. 1891, p. CXII ${ }^{2}$ )]. 15 Juni 1893 strandde een gaaf exemplaar te Callantsoog, dat bewaard wordt in de fauna-collectie van "Artis".

5. Pelamys sarda (Bloch), Juni $18 \% 8$ een exemplaar nabij Bergen op Zoom gevangen [A. A. W. Hobrecht, Tijdschr. Ned. Dierk. Ver. IV. Versl. Vergad. 1878. p. 9]. Daar de visschers een naam voor hem hadden en hem "bonitertje" noemden, schijnt hij meer bij ons voor te komen. C. J. Botremanne [Tijdschr. Ned. Dierk. -Ter. V. 1881 Versl. Vergad. p. CIX] vermeldt hem dan ook van de Oosterschelde. Overigens is deze pelagische soort uit den Atlantik en uit de Middellandsche Zee bekend onder den naam Bonito.

C. J. Bottemanne ['Tijdschr. Ned. Dierk. Ver. (2) IV. Versl. Vergad. 1894, p. LXXX]

1) H. C. REDEKE, Rapport over onderzoekingen betreffende de visscherij in de Zuiderzee 1917.

2) De Heer VAN BEMMELFN teekent hierbij aan, dat het het zevende exemplaar dier soort is, dat aan onze kust is waargenomen. 
noemt ook Thynnus pelamys (L.) uit de Schelde. Daar deze visch voorkomt in de tropische en warme deelen van den Atlantik en Indik, is dit vermoedelijk eene verwarring met Thynnus thynnus (L.) den tonijn, die wel eens door trawlers uit volle zee aangebracht wordt.

6. Centrolophus britannicus (Gthr.), 27 April 1912 werd op de Westpunt van den "Onrust" op Texel een ex. op strand geworpen en levend gevangen. Het is zoover mij bekend het vierde bekende exemplaar van deze vischsoort, waarvan het eerste aan de kust van Cornwales, het tweede niet ver van Boulogne-sur-Mer, het derde in het Kanaal van Capbreton gevangen werd [M. Weber, Tijdschr. Ned. Dierk. Ver. (2) XII. Versl. Verg. 1912, p. LXXXIII].

7. Brama raii (Bloch). Deze visch uit de Middellandsche Zee en den Atlantik tot GrootBritannië, verdwaalt, door den stroom meegevoerd, tot Scandinavië en Noord-Duitschland en ook wel eens tot onze kusten [H. Schlegel, Nat. Hist. v. Nederland, Visschen 1869, p. 16 en A. A. van Bemmelen, Lijst van visschen in Herklots Bouwstoffen Fauna v. Nederland III. 1866 , p. 336].

8. Sciaena aquila (Lac.). De "Ombervisch" behoort ook bij de verdwaalden. A. A. vaN Bemmien [Lijst v. visschen in Herkiots Bouwstoffen Fauna v. Nederland III. 1866, p. 334] geeft een lijstje van in Nederland waargenomen exemplären, maar verșchillende daarvan zijn wel door. visschers van elders aangevoerde exemplaren, daar de visch ook in het Kanaal voorkomt.

9. Cantharus cantharus (L.) (C. lineatus Mont.), 26 Mei 1883 buiten de Noorder- en ZuiderHaaks bij Nieuwediep gevangen [C. Kenbert, Tijdschr. Ned. Dierk. Ver. VI. Versl. Vergad. 1883, p. CLV; Ned. Tijdschr. Dierk. V. 1884, p. 17]. Algemeen in de Middellandsche Zee en den Atlantik, werd hij meermalen aan de Zuid- en Westkust van Engeland en enkele malen aan de Schotsche, Iersche en Noorsehe kusten aangetroffen.

10. Box hoops (L.), 31 Mei 1912 een exemplaar gevangen op de zoog. vischplaats ;de kerkbuurt" bezuiden den vuurtoren van Kijkduin [M. W XII. Versl. Vergad. 1912, p. LXXXIV]. Van de Middellandsche Zee, 'de Canarische eilanden tot de zuidkust van Engeland, waar hij een zeldzame gast is. Voor Nederland werd, voor zoover mij bekend, nog geen exemplaar opgegeven.

11. Pagellus centrodontus (de la Roche). Dat deze niet zeldzaam aan de engelsche kust Jevende visch, verdwaald ook in ons kustwater zou voorkomen, schijnt mij twijfelachtig. De mededeeling van Schregel en A. A. van Bemmelen, dat hij door Katwijksche visschers in de "Noordzee" gevangen werd, bewijst niet veel.

12. Labrus maculatus (Bloch). Juli 1845 een exemplaar door Katwijksche visschers aangebracht [Schlegel, Nat. Hist. v. Nederland, Visschen 1869, p. 20]; twijfelachtig of het uit het kustwater was. 20 Oct. 188.2, een exemplaar te Nieuwediep in een fuik gevangen [C. Kerbert, Tijdschr. Ned. Dierk. Ver. VI. Versl. Vergad. 1883, p. CLV]. Een tweede exemplaar. van Nieuwediep vermeldt Redeк [l.c. (2) X. Versi. Vergad. 1906, p. IV]. Deze van de europeesche kusten bekende visch is dus blijkbaar. een zeldzaam lid onzer fauna.

Dat geldt ook voor de beide volgende soorten:

13. Crenilabrus melops (L.), 22 Augustus 1883 en 9 October 1885 telkens een exemplaar in een fuik bij Nieuwediep gevangen [C. Kerвert, Bijdragen tot de Dierkunde, Feestnummer 1888, p. 82]. Voorts een exemplaar van 1898 en een tweede van 6 Dec. 1912 eveneens nit Nieuwediep in de fauna-collectie van "Artis".

14. Ctenolabrus rupestris (L.). ReDeKE [Tijdschr. Ned. Dierk. Ver. (2) XII. Versl. Vergad. 1910, p. III] vermeldt een exemplaar uit een garnalenkor op de Texelsche gronden. Fen tweede exemplaar, Februari 1911 achter de Haaksgronden bij Nieuwediep gevangen in de faunacollectie van "Artis".

15. Xiphias gladius L., September. 1815 één exemplaar bij Finsterwolde in den Dollart gevangen [Algem. Konst- en Letterbode II, 1815, p. 27] ; 9 Maart 1886 "vertoonden zich verscheiden groote zwaardvisschen nabij de Horst" [A. A. van Bemmelen, Tijdschr. Ned. Dierk. Ver. (2) I. Versl. Vergad. 1886, p. CLXXXI]. Juni 1901 een exemplaar in de Zuiderzee gevangen en te Blokzijl aangebracht [M. WEBER, Tijdschr. Ned. Dierk. Ver. (2) VII. 
Versl. Vergad. 1901, p. XLI]. Komt geregeld voor in de Middellandsche Zee en den Atlantik. Er zijn zoo talrijke vangsten van de engelsche en noorsche kust bekend, dat de zwaardvisch geen zoo zeldzame visch in de Noordzee blijkt te zijn.

16. Blennius gattorugine Bl., September 1899 één exemplaar gevangen in de zoog. Helsdeur bij Texel [C. Kerbert, Tijdschr. Ned. Dierk. Ver. (2) VI. Versl. Vergad. 1899, p. LVIII]. Voor zoover bekend is dit het eerste exemplaar; dat aan onze kust van deze visch gevangen werd, die overigens in de Middellandsche zee en de atlantische kusten van Europa voorkomt. Pholis pholis L. met een gelijke verspreiding, is niet zeldzaam tusschen wier aan de dijken en steenen hoofden der nederlandsche kust.

1\%. Sebastes marinus (L.). Van deze arktische en noord-atlantische visch uit het diepe water verdwaalt er wel eens een zuidwaarts. Zoo vermeldt Hoek [Tijdschr. Ned. Dierk. Ver. (2) V. Versl. Vergad. 1895, p. XXXIX] een exemplaar April 1894 bij de Noorder Haaks gevangen en Redeke [l. c. (2) XII. Versl. Vergad. 1913, p. CXVI] één exemplaar in de haven van Helder opgevischt.

18. Trigla lineata L. Van deze in de Middellandsche zee en aan de Westkusten van Europa voorkomende, maar van Nederland niet bekende visch, vermeldt Hokk [Tijdschr. Ned. Dierk. Ver. (2) III. Versl. Vergad. 1890, p. LXVIII] een exemplaar „door een visscher van Texel in de Noordzee nabij onze kust gevangen".

19. Cottus bubalis Euphr. Het eerst voor de nederlandsche fauna vermeldt door vaN DEN Ende [Versl. d. Werkzaamh. v. d. Ver. t. bevord. d. inlandsche Ichthyologie II (1847) 1849, p. 7 en 24], die een exemplaar ontving ;van de Zutphensche Vischmarkt; waarschijnlijk afkomstig uit de Zuiderzee"; 1590 één exemplaar vermoedelijk in Texelstroom gevangen [R. T. MaITland, Tijdschr. Ned. Dierk. Ver. III. Versl. Vergad. 1890, p. LXVIII]; Maart 1913 bij Helder een exemplaar [H. C. Redere, 1. c. (2) XII. Versl. Vergad. 1913, p. CVI]. Het dichtst bij is deze soort van Engeland en Helgoland bekend.

20. Aphya pellucida (Nardo), Latrunculus pellucidus (Nardo). November 1913 door J. J. TESCH [Ned. Dierk. Ver. (2) XIII. Versl. Vergad. 1913, p. IX] bij de ton van Breehoorn in het noordelijk deel der Zuiderzee gevangen. Dit is de eerste vondst van deze eenjarige Gobiide, die in de Middellandsche Zee gewoon, ook bekend is uit het Kanaal, de zuidelijke Noordzee en bet Skagerrak.

$\mathrm{Er}$ is nog een andere groep van zeebewoners, die hier kort ter sprake moet komen: de Cetaceen. De walvischachtigen zijn bewoners der volle zee; enkelen onthouden zich ook in het kustwater der zeegaten en zijn als zoodanig echte leden der nederlandsche fauna. Van andere soorten kan dat niet gezegd worden, daar zij wel in het Engelsche Kanaal en in de Noordzee leven, ook wel eens ons strand zullen naderen, maar dan altijd met het gevaar: te stranden, zooals zoo vaak vooral bij stormen gebeurt.

Het is in nederlandsche. fauna-geschriften gebruik geworden alle Cataceen op te nemen, waarvan gestrande exemplaren bekend geworden zijn. Dit doende mag men niet uit het oog verliezen, dat daaronder dan ook soorten zijn, die niet alleen niet bij ons fauna-gebied behooren, als zijnde geen bewoners van het litorale water, maar die zelf in de naburige zeeen niet t'huis behooren. Dit zijn dan in der daad verdwaalde gasten.

Als zoodanig is in de eerste plaats te noemen de Potvisch (Physeter macrocephalus L.). Met groote omzichtigheid heeft vas DeINSE ${ }^{1}$ ) de ongeveer 40 strandingen, die vanaf 1521 tot. 1781 van dezen walvisch in Nederland plaats hadden, in een lezenswaard artikel te boek gesteld.

Vervolgens heeft vaN OoR'r een lijst gegeven van de Cetaceen-soorten, die tot heden aan de Nederlandsche kust zijn waargenomen ${ }^{2}$ ).

Als ontwijfelbaar verdwaalde gasten, daar zij ook in de naburige zeeen niet inheemsch zijn, wil ik, behalve den potvisch, noemen; Delphinus delphis (L.), Steno rostratus (Cuv.), Lagenorhynchus albirostris (Gray), Monodon monoceros (L.), Balaenoptera borealis (Lesson).

1) A. B. van DeInse, ín Zoolog. Mededeelingen IV. 1918, p. 22

1) E. D. VAN OORT, in Zoolog. Mededeelingen IV. 1918, p. 54. 
$\mathrm{Na}$ de immigratie-mogelijkheden aangeduid te hebben zijn wij thans zoover gevorderd, dat wij van andere gezichtspunten uit andermaal samenvattend een blik op onze fauna werpen kunnen.

Zooals in elke fauna kunnen wij de volgende groepen onderscheiden:

1. endemische vormen, vormen dus, die eigen zijn aan het nederlandsche fauna-gebjed en elders niet voorkomen.

In een land van de geringe afmeting van Nederland, dat bovendien in een uithoek van een groote continentale landmassa ligt, waarvan het noch door gebergten, noch door groote rivieren gescheiden is, waar in tegendeel de rivieren juist ingangspoorten voor invasie vormen, is het voorkomen van eigen soorten niet te verwachten.

Het ware denkbaar, dat een soort, die vroeger een ruimere verspreiding had, bij ons als relict achtergebleven is, zoo als wellicht het „vuurvlindertje" (Chrysophanes hippothö̈ L., $C h r$. dispar Hw.), maar het zou dan niet "endemisch" zijn, maar bij de volgende categorie behooren.

2. autochthone vormen, die in Nederland uit nederlandsche ouders geboren worden, maar niet eigen alleen aan dat land zijn. Hierbij behoort de overgroote massa der nederlandsche dieren, want daaronder vallen ook immigranten, die bij ons inheemsch geworden zijn.

Wij kunnen de endemische en autochtone vormen ook als indigenen bestempelen, in tegenstelling met de gasten, zooals Syrrhaptes (p. 17r), Acherontia en Deilaphila (p. 177), zooals een aantal van de bovengenoemde visschen en Cetaceen, die bij ons geen stamsoorten zijn. In tegenstelling ook met passanten, die vooral onder de vogels vertegenwoordigd zijn. In tegenstelling eindelijk met de "accidenteele" soorten, die boven ter sprake kwamen als onverwachte geintroduceerden of passieve immigranten. Zij komen op een of andere kunstmatige wijze door ongewild toedoen van den mensch met schepen, handelswaren enz. in ons land of door aanspoelsel van rivieren of langs een anderen natuurlijken weg. Zij brengen het in den regel niet tot leden onzer fauna; daar zij na korteren of langeren tijd weer te gronde gaan. Houden zij zich staande, dan is dat gewoonlijk onder omstandigheden, die niet als natuurlijke kunnen beschouwd worden: zoo in pakhuizen, verwarmde kassen of andere verwarmde localiteiten e. d. m.

Dat de relicten onder de autochthone vormen hun plaats vinden even goed als de immigranten, die zich in Nederland ingeburgerd hebben, ligt voor de hand. Het zijn trouwens begrippen van een ander karakter, waaraan het historische moment der wordingsgeschiedenis der fauna ten grondslag ligt. Aan toekomstige studiën is het voorbehouden deze wordingsgeschiedenis verder te doorgronden. 